\title{
Sürdürülebilir Turizm Konulu Lisansüstü Tezlerin Bibliyometrik Profili
}

\section{Bibliometric Profile of Postgraduate Theses in Tourism Literature Related With Sustainable Tourism}

\author{
Arş. Gör. Özge GÜDÜ DEMIRBULAT \\ Balıkesir Üniversitesi \\ Turizm Fakültesi \\ E-posta: ozgegudu@hotmail.com \\ Orcid Id: 0000-0001-7652-7966
}

\author{
Yrd. Doç. Dr. Nuray TETIKK DiNÇ \\ Balıkesir Üniversitesi \\ Turizm Fakültesi \\ E-posta: ntetik80@yahoo.com \\ Orcid Id: 0000-0002-1366-3714
}

\section{Öz}

Bu çalışmada, 1987-2015 yılları arasında turizm yazınında sürdürülebilir turizm ile ilgili lisansüstü tezlerin çeşitli parametreler çerçevesinde bibliyometrik özelliklerinin belirlenmesi amaçlanmıştır. Sürdürülebilir turizm konusunda alanyazının genel özelliklerini ortaya koymak ve bu alanda çalışacak araştırmacılara kolaylık sağlamak da araştırmanın bir diğer amacını oluşturmaktadır. Bu amaçla çalışmada, YÖK (Yükseköğretim Kurulu) veri tabanında 1987-2015 yılları arasında sürdürülebilir turizm konusunda yayınlanan 41 yüksek lisans ve 21 doktora tezi, "tez türü", "yayınlandığı yıl”, "yayınlandığı üniversite”, "yayınlandığı enstitü”, "yayınlandığı anabilim dalı" ve "tezin çalışma konusu" gibi bibliyometrik özellikleri açısından incelenmiştir. Veri tabanında yer alan çalışmalara ilişkin bilgiler istatistiki analiz paket programına yüklenerek, verilerin sıklık ve yüzde analizleri yapılmıştır. Yapılan incelemeler sonucunda, üniversiteler arasında en fazla lisansüstü tezin İstanbul Üniversitesi bünyesinde hazırlandığı belirlenmiştir.

Anahtar Kelimeler: Turizm, sürdürülebilir turizm, bibliyometri.

\begin{abstract}
In this study, it has been aimed to determine the bibliometric characteristics of postgraduate theses in tourism literature related with the sustainable tourism between the years of 1987 and 2015 in frames of various parameters. General features of the literature on sustainable tourism and provide convenience to reveal researchers to work in this area constitute a further object of this research. With that purpose, postgraduate theses registered in the website of Directorate of Council of Higher Education were reviewed in terms of some bibliometric characteristics (such as "type of thesis", "release year", "university released", "institute released", "department released" and "study topic of thesis"). Therefore, 41 postgraduate and 21 doctorate thesis related with the sustainable tourism included in scope of the study. The recorded studies were subjected to statistical analysis, data analysis was conducted of the frequencies and percentages. In result of the study, it was identified that the most postgraduate and doctorate thesis were prepared in Istanbul University.
\end{abstract}

Keywords: Tourism, sustainable tourism, bibliometric. 


\section{Giriş}

Bir ülkede, yörede ya da bölgede turizmin gelişmesi esnasında, turizmin temel unsurları niteliğindeki doğal ve sosyo-kültürel kaynakların geri dönüşü olmayacak bir şekilde zarar görebilmesi söz konusu olabilmektedir. Bu zararlardan en az düzeyde etkilenmek amacıyla 1970'li yıllarda ve sonrasında sürdürülebilirlik, sürdürülebilir kalkınma ve sürdürülebilir turizm kavramları ortaya çıkmıştır (Keskin ve Örgün, 2015: 31). Ekonomik ve coğrafi kapsamı dikkate alındığında, turizm sektörünün hiç şüphesiz dünyanın en büyük sektörü olduğu söylenebilir. Bu kapsamda turizm, pek çok küresel sorunun çözümünde önemli bir role sahiptir. Özellikle de sürdürülebilir turizm, bu süreçte ağırlıklı bir yapı ortaya koymaktadır (Kuşat, 2011: 34). Türkiye turizmi ile ilgili yapılan uzun dönemli planlarda turizmin tüm aylara yayılması ve farklı turizm ürünlerinin oluşturulması ya da çeşitlendirilmesine yönelik önerilerle birlikte turizmin sürdürülebilirliği üzerinde önemle durulmaktadır. Türkiye'de 2023 Turizm Stratejisi Eylem Planı 2007-2013 çerçevesinde bölgeler arasındaki gelişme farklılıklarının giderilerek, sürdürülebilir kalkınma hedefine katkı sağlaması açısından sürdürülebilir turizm yaklaşımı ana unsur olarak belirlenmiştir (Çalık, 2014: 5; Keleş ve diğ., 2015: 467).

Herhangi bir bilim dalına ilişkin olarak alanyazının belli dönemlerde incelenmesi, o bilim dalındaki gelişmelerin ortaya konulması açısından önemlidir (Çiçek ve Kozak, 2012: 196). Nitekim bu tür bir incelemenin belirli sıklıktaki zaman dilimlerinde gerçekleştirilmesiyle, inceleme konusu olan bilim dalı ya da disiplindeki gelişme çizgisini ortaya çıkarmak söz konusu olabilmektedir (Kozak, 2001: 26). Turizm, her geçen gün önem kazanan ve ekonomiye yüksek düzeyde katkı veren bir hizmet sektörüdür. Bu katkının büyüklüğü sadece elde edilen turizm gelirlerinin yükselmesi ile sınırlı kalmayıp, bu alanda teorik ve araştırmaya dayalı çalışmaların da hızla artmasını ortaya çıkarmaktadır. Tüm bu gelişmeler, turizm alanında hazırlanan lisansüstü tezlerin nitelik ve nicelik açısından incelenmesini gerekli kılmaktadır (Güçlü Nergiz, 2014: 212). Bibliyometrik yöntemler kullanılarak belirli bir disiplinde, belirli bir ülkede çalışılan konu başlıkları, bu konuları çalışan yazarlar, yazarlar arası işbirliği ile fazla ya da az çalışma yapılan konu başlıkları belirlenebilmektedir (Zan, 2012: 15).

Turizmin bir bilgi alanı olarak büyümesi ve bu konuda yayın yapan akademisyen sayısının artması, bilim adamlarının ve yayın kuruluşlarının turizm yazınına sağladıkları katkıların incelenmesine duyulan merak, kişiler veya kuruluşların araştırma performansının değerlendirilmesi intiyacı bibliyometri yönteminin turizm alanındaki çalışmalar için tercih edilmesinde bir etken olmuştur (Temizkan ve diğ., 2015: 395). Başka bir ifadeyle; yayın yapmanın yanı sıra bilim insanlarına ve bilimsel yayınlara ilişkin çok sayıda göstergenin dikkate alınmaya başlanması ile bibliyometrik analizler önem kazanmaya başlamıştır (Şahin ve Acun, 2015: 1458). Ziegler (2009: 13-14), bibliyometrik analizin; bilimsel araştırmaların belirli ölçütlere göre tanımlanması, incelenmesi ve bir değerlendirmede bulunabilmek için kullanıldığını ifade etmiştir. Bu çerçevede, bibliyometrik analiz; belirli bir alan/konu ve kapsam belirlenerek, ilgili kapsamdaki araştırmaların düzenli bir değerlendirmesini içermektedir. Kısacası; bibliyometri, akademik yayınların çeşitli unsurlarının (yazar, konu, yıl, sayfa sayısı, yapılan atıflar vb.) sayısal analizler ve istatistikler yardımıyla incelenmesi ile ilgilenmektedir. Bibliyometrik analizler tanımlayıcı nitelikte (belirli bir yılda yayınlanan makale sayısının belirlenmesi) olabileceği gibi, değerlendirici nitelikte de (bir makalenin kendisinden sonra gelen araştırmaları ne şekilde etkilediğini ortaya koymak için atıf analizi yapılması) olabilirler (Yozgat ve Kartaltepe, 2009: 150). 
Yükseköğretim Kurulu Başkanlığı (YÖK) Ulusal Tez Merkezi, 1987 yılından itibaren üniversitelerde yapılan yüksek lisans, doktora, sanatta yeterlik ve tıpta uzmanlık tezlerini toplayarak, araştırmacıların hizmetine sunmaktadır. Sistemde 2016 Şubat ayı itibariyle 411,928 tez (sanatta yeterlilik, yüksek lisans, doktora, tıpta uzmanlık ve diş hekimliği uzmanlık) mevcuttur. Bunlardan 2125 tanesi yüksek lisans tezi, 525 tanesi doktora tezi ve 1 tanesi de sanatta yeterlilik tezi olmak üzere toplam 2651 tanesi, turizm alanındadır (YÖK, 2015). Alanyazın tarandığında turizmle ilgili pek çok bibliyometrik çalışma yapıldığı görülmektedir. Ancak sürdürülebilir turizm ile ilgili herhangi bir bibliyometrik çalışmaya rastlanmamıştır. $\mathrm{Bu}$ husustaki boşluğu doldurabilmek adına, bu çalışmada; 1987-2015 yılları arasında sürdürülebilir turizm konusunda hazırlanan yüksek lisans ve doktora tezleri incelenmiştir. Özel ve Kozak'ın (2012) da ifade ettiği üzere; turizmin farklı alt konu başlıklarında gerçekleştirilecek bibliyometrik çalışmalar, bu alanlara ilişkin kapsamlı bir bakış açısı sağlayarak alana katkıda bulunabilecektir. Dolayısıyla bu çalışmadan elde edilecek bulgular, sürdürülebilir turizm konusunda yayınlanan yüksek lisans ve doktora tezlerinin genel görüntüsünü sayısal verilerle ortaya koyması ve bu alandaki boşluğu doldurması açısından önemli görülmektedir.

\section{2. İlgili Yazın}

Bibliyometrik terimi ilgili yazında ilk olarak kullanımadan önce "istatistiksel bibliyografi" şeklinde E. Wyndham Hulme (1922) tarafından ele alınmış ve daha sonra Pritchard (1969) tarafından istatistiksel bibliyografi terimi yerine "bibliyometri" terimi kullanılmaya başlanmıştır (Kodaş, 2014: 99). Matematiksel ve istatistiksel tekniklerle, yayınlanmış dergi ve kitap gibi bilimsel bilgi paylaşım araçlarının incelenmesinde kullanılan yöntem olarak tanımlanan bibliyometri ile akademik bir alanda yayınlanmış çalışmalar, farklı bibliyometrik özellikler (konu, yıl, katkı sağlayan kurum, kullanılan anahtar sözcükler, eserlerin yazar sayısı, atıflar, ortak atıflar gibi) çerçevesinde incelenerek, bilimsel iletişime ilişkin bazı bulgular elde edilmektedir (Ulu ve Akdağ, 2015: 7). Bu çerçevede; bibliyometrik çalışmalar, incelenen bilim dalına, ülke ve/veya ülke gruplarına, kurumlara veya kişilere ait bilimsel çalışmaların değerlendirilmesine ve mevcut durumuna yönelik saptamalarda bulunulmasına olanak vermektedir (Şakar Denktaş ve Cerit, 2013: 38). Başka bir ifadeyle; bibliyometrik araştırmalarda belgelerin ya da yayınların belirli özellikleri analiz edilerek bilimsel iletişime ilişkin çeşitli bulgular elde edilmektedir (Al ve Coştur, 2007: 144; Turan, 2014: 3).

Bibliyometrik araştırmalarda, yayınların yıllar itibariyle belirli özellikleri analiz edilerek çeşitli bulgular elde edilmektedir. Kısaca, belgelerle ilgili süreçlerin ölçümü bibliyometrinin alanına girmektedir (Cevizkaya ve diğ., 2014: 102). Türkiye turizm yazını 1920'li yıllardan 2000'lere kadar geçen dönemde, başlangıç döneminde ağır, ancak 1970'li yıllarla birlikte giderek hızlanarak gelişme göstermiştir. 2000 yılında pek çok ülke ile en azından nicelik olarak boy ölçüşebilecek bir alanyazının Türkiye'de oluşturulduğundan rahatııkla söz edilebilir. Gerek alanyazını oluşturan birincil faktörler olan kitap, makale ve bildiri, tez, başvuru kaynağı, istatistik ve araştırmalar gerekse ikincil faktörler (kongre gibi akademik süreli yayınlar, akademik turizm programları) bakımından Türkiye, dünya genelinde önemli bir yere sahip olmaya başlamıştır (Kozak, 2000: 50). Bibliyometrinin turizm alanında gerçekleştirilen çalışmalardaki önemi de giderek artmaktadır. Turizmin bir bilgi alanı olarak büyümesi ve bu konuda yayın yapan bilim adamı sayısının artması bu artışın temel nedenleridir. Bilim adamlarının ve yayın kuruluşlarının turizm yazınına sağladıkları katkıların incelenmesine duyulan merak ile bu kişilerin ve kuruluşların araştırma performansının değerlendirilmesi gereksinimi de bu artışın nedenleri arasında sayılabilir (Özel ve Kozak, 2012: 716-717). 
Chrichton (1978), Dissertation Abstracts International'ın 36-38. sayılarında yer alan turizm ve ilgili alanlarında hazırlanmış 122 doktora tezini incelemiştir. Pizam ve Elanjikal (1982) ise, 1976-1980 yılları arasında Dissertation Abstracts International'da yer alan turizmle ilgili 65 tez üzerine bir araştırma yürütmüşlerdir. Jafari ve Aaser (1988), ABD ve Kanada'daki üniversitelerde turizm ve yakın alanlarında, 1962-1987 yılları arasında hazırlanmış doktora tezleri üzerine bir inceleme gerçekleştirmişlerdir (Kozak, 2000: 21).

Turizm tezleri üzerine gerçekleştirilen bir çalışma 1994 yılında Kozak tarafından yapılmıştır. Bu araştırmada; 1963-1992 yılları arasında Türkiye'de yüksek lisans ve doktora düzeyinde hazırlanmış tezler, bazı parametrelere göre değerlendirilmiştir. Ayrıca inceleme konusu olan dönemde Türkiye'de turizm araştırmalarının gelişme yönü, içeriği ve şekli konularında birtakım değerlendirmeler de söz konusu araştırma kapsamında elde edilmiştir (Kozak, 2001: 27).

Kozak (2001), turizm alanında spesifik bir konu olan turizm pazarlaması yazınının gelişim sürecini değerlendirdiği çalışmasında, Türkiye'de 1972-1998 yılları arasında yayınlanmış 131 yüksek lisans ve doktora tezini incelemiştir. Araştırma sonuçlarına göre, ilgili yıllar arasında en fazla turizm pazarlaması konulu tez, İstanbul Üniversitesi (25) ve Gazi Üniversitesi'nde (24) yayınlanmıştır.

Arıca (2014) tarafından yapılan çalışmada, seyahat işletmeciliği konulu lisansüstü tez çalışmalarının bibliyometrik profillerinin belirlenen parametreler çerçevesinde ortaya konması amaçlanmıştır. Bu doğrultuda, YÖK veri tabanında yer alan 220 tez bibliyometrik analiz yöntemiyle incelenmiştir. Araştırmanın sonucunda, tez çalışmalarının çoğunun 2000 yılı sonrasında ve tamamına yakınının sosyal bilimler enstitülerinde hazırlandığı görülmüştür. Ayrıca tezlerin yazımının belirli üniversitelerde yoğunlaştığı, büyük bir bölümünün yüksek lisans tezi olduğu ve pazarlama disipliniyle ilişkili konuların ön plana çıktığı tespit edilmiştir. Bununla beraber, tezlerin 100-200 sayfa sayısı aralığında yoğunlaştığı, genelinde nicel araştırma paradigmalarının tercih edildiği, uygulama alanı olarak $A$ grubu seyahat acentaları ve havayolu işletmelerinin ön plana çıktığı sonucuna ulaşıımıştır. Çalışmalara danışmanlık yaparak alana en fazla katkı sunan öğretim üyesinin ise Prof. Dr. Necdet Hacıoğlu olduğu ve tezlerin uygulamalarının 0-50 örneklem aralığında yoğunlaştığı görülmüştür.

Aydın (2014) tarafından yapılan bir araştırmada, ticari yiyecek içecek alanına yönelik hazırlanan tezler araştırma konusu olarak seçilmiştir. Bu kapsamda ilgili alana yönelik 1988-2013 yılları arasında hazırlanan 179 tez olduğu belirlenmiştir. Bu araştırma ile söz konusu tezlerin bibliyometrik olarak analiz edilmesi amaçlanmıştır. Bu analiz sonucunda yiyecek içecek alanının bilimsel iletişimine yönelik önemli bulgular elde edilmiştir. Bunlar; ilgili alanda en çok tercih edilen konular, araştırma türü, araştırma yaklaşımı, araştırma alanı, araştırma yürütülen anabilim dalları, üniversiteler, araştırmaya danışmanlık yapan kişiler vb. şeklinde önemli bulgulardan oluşmaktadır.

Güçlü Nergiz (2014), Türkiye'de 1990-2013 yılları arasında turizm alanında hazırlanan yüksek lisans ve doktora tezlerinin genel bir değerlendirmesini yaptığı çalışmada; YÖK internet sitesinde kayıtlı olan lisansüstü tezleri bibliyometrik bazı özellikler açısından incelemiştir. Tezler adı geçen internet sitesinde turizm, otel, otel işletmesi, seyahat acentası ve yiyecek-içecek işletmesi anahtar kelimeleri ile taranmış, 1565 yüksek lisans ve 783 doktora tezi olmak üzere toplam 2348 tez araştırma kapsamına dahil edilmiştir. Araştırma sonucunda 1990-2013 yılları arasında tez çalışmaları içerisinde en fazla yüksek lisans tezinin Gazi Üniversitesi'nde, doktora tezinin ise Dokuz Eylül Üniversitesi'nde hazırlandığı belirlenmiştir. Zaman açısından 
incelendiğinde en fazla sayıda tezin 2010-2013 yılları arasında hazırlandığı saptanmıştır. Konu açısından yüksek lisans tezlerinde turizm, işletme ve mimarlık konulu tezler ilk sıralarda yer alırken; doktora tezlerinde turizm, işletme ve coğrafya konulu tezler şeklinde bir dağılım göze çarpmaktadır.

Turan (2014) tarafından yapılan bir araştırmada; YÖK veri tabanında 1984-2013 yılları arasında yayınlanan, 1670 turizm konulu yüksek lisans tezinin, bibliyometrik özelliklerinin belirlenmesi amaçlanmıştır. Yapılan incelemeler sonucunda, tüm üniversiteler arasında yüksek lisans tezinin en fazla İstanbul Üniversitesi bünyesinde hazırlandığı belirlenmiştir. Yardımcı doçent unvanlı öğretim üyelerinin danışmanlık yaptığı belirlenen yüksek lisans tezleri, pazarlama alanında yoğunlaşmıştır. İncelenen tezlerin büyük çoğunluğu üniversitelerin sosyal bilimler enstitüsü ve turizm işletmeciliği anabilim dalı bünyesinde hazırlanmıştır. Ayrıca söz konusu bu tezlerin uygulama alanlarının ağırlıklı olarak Antalya olduğu belirlenmiştir. Tezlerin daha önceki yıllara göre 2000'li yıllar itibariyle sayısında önemli artışlar olduğu ortaya çıkan bulgular arasındadır.

Cevizkaya, İlsay ve Avcıkurt (2015), 2000-2013 yılları arasında turizm alanyazınında engellilerle ilgili çalışmaların çeşitli parametreler çerçevesinde bibliyometrik özelliklerinin belirlenmesini amaçladıkları çalışmada; 515 yüksek lisans ve 88 doktora olmak üzere toplam 603 tezi incelemişlerdir. Araştırma sonucunda 20002013 yılları arasında yüksek lisans ve doktora tezinin çoğunlukla Gazi üniversitesinde hazırlandığı saptanmıştır. Hazırlanan tezler yıllar bazında incelendiğinde, büyük çoğunluğunun 2010-2013 yılları arasında yoğunlaştığı belirlenmiştir. Konu açısından ise eğitim ve öğretim, spor ve psikoloji alanları ilk sıralarda yer alırken turizm alanının ise 6 . sırada olduğu tespit edilmiştir.

Şahin ve Acun (2015) YÖK veri tabanında 1989-2015 yılları arasında (26 yıl) turist rehberliği alanında yayınlanan 30 yüksek lisans ve 8 doktora tezini çeşitli parametreler çerçevesinde değerlendirmişlerdir. Yapılan incelemeler sonucunda, tezlerin en fazla Balıkesir Üniversitesi bünyesinde hazırlandığı ortaya çıkmıştır. Tezlerde en çok çalışılan konuların ise turist rehberliği eğitimi ve turist rehberlerinin rolleri ile ilgili olduğu belirlenmiştir.

\section{Araştırmanın Yöntemi}

Bu çalışmanın amacı; 1987-2015 yılları arasında turizm yazınında sürdürülebilir turizm ile ilgili lisansüstü tezlerin çeşitli parametreler çerçevesinde bibliyometrik özelliklerinin belirlenmesidir. Bu amaçla hazırlanan çalışmada bibliyometrik analiz tekniği kullanılmıştır. Bibliyometrik yöntemde, özellikle akademik bir alanda yapılmış çalışmaların belirli özellikleri analiz edilerek, bilimsel iletişime ilişkin çeşitli bulgular elde edilmektedir. Çalışmanın kapsamında 1987-2015 yılları arasında sürdürülebilir turizm konusunda yazılan yüksek lisans ve doktora tezleri incelenmiştir. İncelemeye alınan tezlere Yükseköğretim Kurulu'na bağlı Ulusal Tez Merkezi internet veri tabanı üzerinden erişilmiştir.

Araştırma evreninin mümkün olduğunca tamamının temsili ile doğruluk payının artması ve daha anlamlı sonuçlar elde edilmesi amacıyla çeşitli şekillerde veri tabanı taraması yapılmıştır. Avcıkurt (2015) ve Swarbrooke (1999)'a göre sürdürülebilir turizm kavramı; alternatif turizm, çevreye duyarlı turizm, ekoturizm, sorumlu turizm, topluma dayalı turizm, yeşil turizm ve yumuşak turizm gibi turizm türlerinin tümünü içermektedir. Buradan yola çıkarak; incelemenin yapılabilmesi için YÖK'ün tez tarama motorunda "sürdürülebilir turizm", "alternatif turizm", "çevreye duyarlı turizm”, "ekoturizm”, "sorumlu 
turizm", "topluma dayalı turizm", "yeşil turizm" ve "yumuşak turizm" gibi anahtar sözcüklerle tarama yapılmıştır. Yapılan tarama sonucunda 41 yüksek lisans ve 21 doktora olmak üzere toplam 62 lisansüstü teze ulaşılmıştır.

Tez çalışmalarının bibliyometrik özelliklerinin incelenmesi için tez künyelerinde yer alan "tez türü", "yayınlandığı yıl”, "yayınlandığı üniversite", "yayınlandığı enstitü", "yayınlandığı anabilim dalı" ve "tezin çalışma konusu" şeklinde parametreler belirlenmiştir. Söz konusu parametrelere ilişkin verilerin tamamı, istatistik analiz programına aktarılarak yüzde ve sıklık değerleri hesaplanmıştır. Çalışmada YÖK Ulusal Tez Merkezi'nin https://tez.yok.gov.tr internet adresinden ulaşılan kayıtlarda 10.12.2015 / 25.12.2015 tarihleri arasında yapılan taramaların sonuçları esas alınmıştır.

\section{Bulgular ve Yorum}

Sürdürülebilir turizm ile ilgili 1987-2015 yılları arasında toplam 62 lisansüstü tez yapılmıştır. Araştırma kapsamında bu tezlerin tamamı incelenmiştir. Tezlerin türüne göre dağılımları Tablo 1'de verilmiştir.

Tablo 1: Lisansüstü Tezlerin Türüne İlişkin Sayısal ve Yüzdesel Dağılım

\begin{tabular}{|l|c|c|}
\hline Tez Türü & Sayı & Yüzde \\
\hline Yüksek Lisans & 41 & 66,1 \\
\hline Doktora & 21 & 33,9 \\
\hline Toplam & $\mathbf{6 2}$ & $\mathbf{1 0 0}$ \\
\hline
\end{tabular}

Tablo 1'de görüldüğü üzere; incelenen tezlerin 41'i $(\% 66,1)$ yüksek lisans ve 21 'i $(\% 33,9)$ doktora tezidir.

Lisansüstü tezlerin yıllara göre dağılımı incelendiğinde ise; 1987-1993 yılları arasında sürdürülebilir turizm konusunda yapılmış lisansüstü teze rastlanamamıştır. Tablo 2'de tezlerin yıllara göre dağılımı yer almaktadır.

Tablo 2: Lisansüstü Tezlerin Yıllara Göre Dağılımı

\begin{tabular}{|c|c|c|c|c|c|c|c|c|c|}
\hline \multirow{2}{*}{ Yıl } & \multicolumn{2}{|c|}{ Yüksek Lisans } & \multicolumn{2}{|c|}{ Doktora } & \multirow{2}{*}{ Yıl } & \multicolumn{2}{c|}{$\begin{array}{l}\text { Yüksek } \\
\text { Lisans }\end{array}$} & \multicolumn{2}{c|}{ Doktora } \\
\cline { 2 - 6 } & Sayı & Yüzde & Sayı & Yüzde & & Sayı & Yüzde & Sayı & Yüzde \\
\hline $\mathbf{1 9 9 4}$ & 1 & 2,4 & - & - & $\mathbf{2 0 0 5}$ & - & - & - & - \\
\hline $\mathbf{1 9 9 5}$ & 2 & 4,9 & - & - & $\mathbf{2 0 0 6}$ & - & - & - & - \\
\hline $\mathbf{1 9 9 6}$ & 1 & 2,4 & 1 & 4,8 & $\mathbf{2 0 0 7}$ & 1 & 2,4 & 1 & 4,8 \\
\hline $\mathbf{1 9 9 7}$ & - & - & 1 & 4,8 & $\mathbf{2 0 0 8}$ & - & - & 1 & 4,8 \\
\hline $\mathbf{1 9 9 8}$ & - & - & 1 & 4,8 & $\mathbf{2 0 0 9}$ & - & - & 2 & 9,5 \\
\hline $\mathbf{1 9 9 9}$ & - & - & 2 & 9,5 & $\mathbf{2 0 1 0}$ & 4 & 9,8 & 2 & 9,5 \\
\hline $\mathbf{2 0 0 0}$ & 1 & 2,4 & - & - & $\mathbf{2 0 1 1}$ & 3 & 7,3 & 1 & 4,8 \\
\hline $\mathbf{2 0 0 1}$ & 2 & 4,9 & - & - & $\mathbf{2 0 1 2}$ & 1 & 2,4 & 2 & 9,5 \\
\hline $\mathbf{2 0 0 2}$ & 3 & 7,3 & - & - & $\mathbf{2 0 1 3}$ & 3 & 7,3 & 1 & 4,8 \\
\hline $\mathbf{2 0 0 3}$ & 3 & 7,3 & $\mathbf{3}$ & $\mathbf{1 4 , 3}$ & $\mathbf{2 0 1 4}$ & $\mathbf{1 1}$ & $\mathbf{2 6 , 8}$ & 2 & 9,5 \\
\hline $\mathbf{2 0 0 4}$ & - & - & 1 & 4,76 & $\mathbf{2 0 1 5}$ & 5 & 12,2 & - & - \\
\hline Toplam & $\mathbf{4 1}$ & $\mathbf{1 0 0}$ & & & Toplam & & & $\mathbf{2 1}$ & $\mathbf{1 0 0}$ \\
\hline
\end{tabular}

Tablo 2'ye göre; sürdürülebilir turizm konusunda en fazla yüksek lisans tezinin 2014 yılında $(\% 26,8)$ yapıldığı görülmektedir. Doktora tezleri incelendiğinde ise; en fazla tezin yapıldığı yıl olarak 2003 yılı $(\% 14,3)$ karşımıza çıkmaktadır. Öte yandan; 
1987-1995 yılları arasında sürdürülebilir turizm konusunda yapılmış doktora tezine rastlanmazken; ilk doktora tezinin 1996 yılında yapıldığı görülmektedir. Tablo 3'te tezlerin üniversitelere göre dağılımı gösterilmiştir.

Tablo 3: Lisansüstü Tezlerin Üniversitelere Göre Dağılımı

\begin{tabular}{|c|c|c|c|c|}
\hline \multirow[t]{2}{*}{ Hazırlandığı Üniversite } & \multicolumn{2}{|c|}{ Yüksek Lisans } & \multicolumn{2}{|c|}{ Doktora } \\
\hline & Sayı & Yüzde & Sayı & Yüzde \\
\hline Afyon Kocatepe Üniversitesi & - & - & 2 & 9,5 \\
\hline Ankara Üniversitesi & 2 & 4,9 & 2 & 9,5 \\
\hline Akdeniz Üniversitesi & 2 & 4,9 & 1 & 4,8 \\
\hline Atılım Üniversitesi & 1 & 2,4 & - & - \\
\hline Balıkesir Üniversitesi & 3 & 7,3 & 1 & 4,8 \\
\hline Boğaziçi Üniversitesi & 1 & 2,4 & - & - \\
\hline Çanakkale Onsekiz Mart Üniversitesi & 2 & 4,9 & 1 & 4,8 \\
\hline Çukurova Üniversitesi & - & - & 1 & 4,8 \\
\hline Dicle Üniversitesi & 1 & 2,4 & - & - \\
\hline Dokuz Eylül Üniversitesi & 2 & 4,9 & 4 & 18,9 \\
\hline Eskişehir Osmangazi Üniversitesi & 1 & 2,4 & - & - \\
\hline Gazi Üniversitesi & 1 & 2,4 & 2 & 9,5 \\
\hline Gaziantep Üniversitesi & 1 & 2,4 & - & - \\
\hline Hacettepe Üniversitesi & 2 & 4,9 & - & - \\
\hline İstanbul Üniversitesi & 6 & 15,1 & - & - \\
\hline İstanbul Teknik Üniversitesi & 1 & 2,4 & 3 & 14,3 \\
\hline İzmir Yüksek Teknoloji Enstitüsü & 1 & 2,4 & - & - \\
\hline Koç Üniversitesi & 1 & 2,4 & - & - \\
\hline Mersin Üniversitesi & 2 & 4,9 & - & - \\
\hline Mimar Sinan Güzel Sanatlar Üniversitesi & - & - & 1 & 4,8 \\
\hline Muğla Sıtkı Koçman Üniversitesi & 2 & 4,9 & - & - \\
\hline Mustafa Kemal Üniversitesi & 1 & 2,4 & - & - \\
\hline Nevşehir Hacı Bektaş Veli Üniversitesi & 1 & 2,4 & - & - \\
\hline Ortadoğu Teknik Üniversitesi & 1 & 2,4 & - & - \\
\hline Sakarya Üniversitesi & 2 & 4,9 & 1 & 4,8 \\
\hline Selçuk Üniversitesi & 1 & 2,4 & - & - \\
\hline Süleyman Demirel Üniversitesi & 1 & 2,4 & - & - \\
\hline Yıldız Teknik Üniversitesi & 1 & 2,4 & 2 & 9,5 \\
\hline Zonguldak Karaelmas Üniversitesi & 1 & 2,4 & - & - \\
\hline Toplam & 41 & 100 & 21 & 100 \\
\hline
\end{tabular}

Tablo 3'e göre; yüksek lisans tezi en çok İstanbul Üniversitesi'nde (\%15,1) ve en fazla doktora tezi en çok Dokuz Eylül Üniversitesi'nde $(18,9)$ yapılmıştır. Tablo 4 'te tezlerin enstitülere göre dağılımı verilmiştir.

Tablo 4: Lisansüstü Tezlerin Bağlı Olduğu Enstitüye Göre Dağılımı

\begin{tabular}{|c|c|c|c|c|}
\hline \multirow{2}{*}{ Enstitü } & \multicolumn{2}{|c|}{ Yüksek Lisans } & \multicolumn{2}{c|}{ Doktora } \\
\cline { 2 - 5 } & Sayı & Yüzde & Sayı & Yüzde \\
\hline Sosyal Bilimler Enstitüsü & 33 & 80,5 & 13 & 61,9 \\
\hline Fen Bilimleri Enstitüsü & 8 & 19,5 & 7 & 33,3 \\
\hline Eğitim Bilimleri Enstitüsü & - & - & 1 & 4,8 \\
\hline Toplam & $\mathbf{4 1}$ & $\mathbf{1 0 0}$ & $\mathbf{2 1}$ & $\mathbf{1 0 0}$ \\
\hline
\end{tabular}

Tablo 4'te görüldüğü üzere; yüksek lisans tezlerinin hazırlandığı enstitüler dağılımında ilk sırada 33 tez ile sosyal bilimler enstitüsü gelmektedir. Bunu 8 tez ile fen bilimleri enstitüsü izlemektedir. Doktora tezlerinin hazırlandığı enstitü dağıımına 
bakıldığında ise, 13 tez sosyal bilimler enstitüsü, 7 tez fen bilimleri enstitüsü ve 1 tez eğitim bilimleri enstitüsü kapsamında hazırlanmıştır.

Araştırma kapsamında lisansüstü tezlerin hazırlandığı anabilim dalları da incelenmiştir. Ancak bu noktada; bir kısım tezin öz, anahtar kelimeler, anabilim dalı ve konu bilgilerinde eksikler bulunduğu görülmüştür. Örneğin, YÖK ulusal tez merkezi veri tabanında yüksek lisans tezlerinin \%17,1'inin ve doktora tezlerinin \%23,8'inin anabilim dalları belirtilmemiştir. Tablo 5'te tezlerin anabilim dallarına göre dağılımı verilmiştir.

Tablo 5: Lisansüstü Tezlerin Anabilim Dalına Göre Dağılımı

\begin{tabular}{|l|c|c|c|c|}
\hline \multirow{2}{*}{ Anabilim Dalı } & \multicolumn{2}{c|}{ Yüksek Lisans } & \multicolumn{2}{c|}{ Doktora } \\
\cline { 2 - 5 } & Sayı & Yüzde & Sayı & Yüzde \\
\hline Turizm İşletmeciliği & $\mathbf{1 4}$ & $\mathbf{3 4 , 1}$ & $\mathbf{5}$ & $\mathbf{2 3 , 8}$ \\
\hline Turizm Işletmeciliği ve Otelcilik & 4 & 9,8 & 2 & 9,5 \\
\hline Coğrafya & 2 & 4,9 & 3 & 14,3 \\
\hline İşletme & 4 & 9,8 & 1 & 4,8 \\
\hline İktisat & 1 & 2,4 & 1 & 4,8 \\
\hline Şehir ve Bölge Planlama & 2 & 4,9 & - & - \\
\hline Kamu Yönetimi & 2 & 4,9 & - & - \\
\hline Mimarlık & 2 & 4,9 & 2 & 9,5 \\
\hline Peyzaj Mimarlığı & 1 & 2,4 & 1 & 4,8 \\
\hline Uluslararası İlişkiler & 1 & 2,4 & - & - \\
\hline Anadolu Medeniyetleri ve Kültürel Miras Yönetimi & 1 & 2,4 & - & - \\
\hline Turizm İşletmeciliği Eğitimi & - & - & 1 & 4,8 \\
\hline Diğer (Belirtilmemiş) & 7 & 17,1 & 5 & 23,8 \\
\hline Toplam & $\mathbf{4 1}$ & $\mathbf{1 0 0}$ & $\mathbf{2 1}$ & $\mathbf{1 0 0}$ \\
\hline
\end{tabular}

Tablo 5'e göre; 14 yüksek lisans tezinin ve 5 doktora tezinin Turizm İşletmeciliği Anabilim Dalı'nda hazırlandığı görülmektedir. Buna göre; sürdürülebilir turizm konusunda hazırlanan lisansüstü tezlerin büyük kısmının üniversitelerin Turizm İşletmeciliği Anabilim Dalı bünyesinde hazırlandığı görülmektedir. Tablo 6'da lisansüstü tezlerin konularına göre dağılımı verilmiştir.

Tablo 6: Lisansüstü Tezlerin Konularına Göre Dağılımı

\begin{tabular}{|l|c|c|c|c|}
\hline \multicolumn{1}{|c|}{ Konu } & \multicolumn{2}{c|}{ Yüksek Lisans } & \multicolumn{2}{c|}{ Doktora } \\
\cline { 2 - 6 } & Sayı & Yüzde & Sayı & Yüzde \\
\hline Sürdürülebilir destinasyon yönetimi ve planlaması & $\mathbf{6}$ & $\mathbf{1 4 , 6}$ & $\mathbf{3}$ & $\mathbf{1 4 , 3}$ \\
\hline Sürdürülebilir turizm gelişimi & $\mathbf{5}$ & $\mathbf{1 2 , 2}$ & $\mathbf{2}$ & $\mathbf{9 , 5}$ \\
\hline Konaklama işletmeleri ve sürdürülebilir turizm ilişkisi & $\mathbf{4}$ & $\mathbf{9 , 8}$ & - & - \\
\hline $\begin{array}{l}\text { Bir destinasyonda sürdürülebilir turizm olanaklarının } \\
\text { araştırılması }\end{array}$ & $\mathbf{4}$ & $\mathbf{9 , 8}$ & $\mathbf{3}$ & $\mathbf{1 4 , 3}$ \\
\hline Ziyaretçilerin, sürdürülebilir turizme ilişkin tutumları & 3 & 7,3 & - & - \\
\hline Yerel halkın sürdürülebilir turizme ilişkin tutumu & 2 & 4,9 & 1 & 4,8 \\
\hline Sürdürülebilir turizmde STK'ların rolü & 2 & 4,9 & - & - \\
\hline Sürdürülebilir turizm politikaları & 2 & 4,9 & - & - \\
\hline Çevre duyarlı sürdürülebilir turizm modeli & 2 & 4,9 & 1 & 4,8 \\
\hline $\begin{array}{l}\text { Ekoturizm kaynaklarının sürdürülebilir turizm açısından } \\
\text { değerlendirilmesi }\end{array}$ & - & - & 2 & 9,5 \\
\hline Sürdürülebilir turizm kapsamında ekomüzeciliğin incelenmesi & 1 & 2,4 & - & - \\
\hline Sürdürülebilir turizmde eko etiket uygulamalarının rolü & 1 & 2,4 & - & - \\
\hline $\begin{array}{l}\text { Doğal, tarihi ve külttürel kaynakların sürdürülebilir turizm } \\
\text { açısından değerlendirilmesi }\end{array}$ & 1 & 2,4 & 1 & 4,8 \\
\hline Sürdürülebilir turizm bağlamında yöre imgesi & - & - & 1 & 4,8 \\
\hline
\end{tabular}


Tablo 6'nın Devamı

\begin{tabular}{|c|c|c|c|c|}
\hline $\begin{array}{l}\text { Sürdürülebilir turizm kapsamında toplumsal ve kültürel kimliğin } \\
\text { korunması }\end{array}$ & - & - & 1 & 4,8 \\
\hline Sürdürülebilir turizmde bölgesel kalkınma & 2 & 4,9 & 2 & 9,5 \\
\hline Sürdürülebilir turizm açısından taşıma kapasitesi & - & - & 1 & 4,8 \\
\hline $\begin{array}{l}\text { Sürdürülebilir bir turizm için ülkesel, bölgesel, yerel risklerin } \\
\text { irdelenmesi }\end{array}$ & - & - & 1 & 4,8 \\
\hline $\begin{array}{l}\text { Sürdürülebilir turizm kapsamında turistik ürün çeşitlendirme } \\
\text { politikaları }\end{array}$ & - & - & 2 & 9,5 \\
\hline $\begin{array}{l}\text { Sürdürülebilir turizm algısının tüketicilerin } \\
\text { memnuniyetleriyle olan ilişkisi }\end{array}$ & 1 & 2,4 & - & - \\
\hline Türk sürdürülebilir turizminin geliştirilmesi için öneriler & 1 & 2,4 & - & - \\
\hline $\begin{array}{l}\text { Sürdürülebilir turizmin bir aracı olarak enerji verimliliği } \\
\text { faaliyetlerini incelemek }\end{array}$ & 1 & 2,4 & - & - \\
\hline Sürdürülebilir turizmde yerel değerler & 1 & 2,4 & - & - \\
\hline $\begin{array}{l}\begin{array}{l}\text { Sürdürülebilir turizm } \\
\text { değerlendirilmesi }\end{array}\end{array}$ & 1 & 2,4 & - & - \\
\hline Kültürel miras yönetimi ve sürdürülebilir turizmin geliştirilmesi & 1 & 2,4 & - & - \\
\hline Toplam & 41 & 100 & 21 & 100 \\
\hline
\end{tabular}

Tablo 6'ya göre yüksek lisans tezleri incelendiğinde; 6 tezin sürdürülebilir destinasyon yönetimi ve planlaması ile ilgili olduğu, 5 tezin bir destinasyonda sürdürülebilir turizm gelişimi ile ilgili olduğu tespit edilmiştir. Ayrıca konaklama işletmeleri ve sürdürülebilir turizm ilişkisi konusunda 4 tezin; bir destinasyonda sürdürülebilir turizm olanaklarının araştırılması konusunda da 4 tezin hazırlandığı belirlenmiştir. Doktora tezleri incelendiğinde ise; 3 tezin sürdürülebilir destinasyon yönetimi ve planlaması; 3 tezin bir destinasyonda sürdürülebilir turizm olanaklarının araştırılması ve 2 tezin de sürdürülebilir turizm gelişimi ile ilgili olduğu görülmektedir.

\section{Sonuç ve Değerlendirme}

Bu çalışmada, YÖK veri tabanında 1987-2015 yılları arasında sürdürülebilir turizm ile ilgili yayınlanan 41 yüksek lisans ve 21 doktora tezi çeşitli parametreler çerçevesinde değerlendirilmiştir. Çalışmanın sonucunda; en fazla yüksek lisans tezinin 2014 yılında, en fazla doktora tezinin ise 2003 yılında yayınlandığı belirlenmiştir. Bu sonuç doğrultusunda sürdürülebilir turizm kavramının lisansüstü tez çalışmalarında özellikle 2000'li yıllardan sonra daha fazla değerlendirilmeye başlandığı söylenebilir. Turizm sektörünün doğal çevreye bağımlı olması, mevcut değerlerin ve kaynakların gelecek nesillerin de kullanımını sağlamak amacıyla korunması gereğini ortaya çıkarmaktadır. Nitekim sektörün devamlılığı mevcut kaynakların sürdürülebilirlik çerçevesinde değerlendirilmesine bağlıdır. Son yıllarda doğal çevrede yaşanan bozulmalar, küresel ısınma, iklim değişikliği gibi sorunlar, özellikle turizm sektörünün sürdürülebilir turizm konusuna ağırlık vermesini gerekli kılmıştır. Sektörde görülen bu ilgiye paralel olarak, bilimsel alanda da konuya olan ilgi giderek artmakta ve lisansüstü tezlerde sürdürülebilir turizm kavramı yoğunluk kazanmaktadır.

Çalışmanın sonuçlarına bakıldığında yüksek lisans tezinin en fazla İstanbul Üniversitesi'nde ve ikinci sırada Balıkesir Üniversitesi'nde hazırlandığı; doktora tezinin ise en fazla Dokuz Eylül Üniversitesi'nde ve ikinci sırada İstanbul Teknik Üniversitesi'nde hazırlandığı belirlenmiştir. Bu sonuç, Turan (2014) tarafından yapılan araştırmanın sonuçlarıyla da benzerlik göstermektedir. Nitekim söz konusu çalışmada da 1984-2013 yılları arasında yayınlanan, 1670 turizm konulu yüksek lisans tezinin en fazla İstanbul Üniversitesi bünyesinde hazırlandığı belirlenmiştir. Bünyesinde turizm disiplinine yönelik bir anabilim dalı olmamasına rağmen, sürdürülebilir turizm 
konusunda hazırlanmış doktora tezi sayısı bakımından İstanbul Teknik Üniversitesi'nin ikinci sırada yer alması dikkati çeken bir sonuçtur.

Ortaya çıkan bir diğer bulgu, lisansüstü tezlerin en fazla Sosyal Bilimler Enstitüsünde yayınlandığı ve tezlerin büyük çoğunluğunun Turizm İşletmeciliği Anabilim Dal'nda hazırlandığıdır. Turizm biliminin sosyal bilimler kapsamında yer alması bu sonuca kanıt gösterilebilecek niteliktedir. Hazırlanan lisansüstü tezlerin konu dağılımları incelendiğinde hem yüksek lisans hem de doktora tezlerinin çoğunlukla destinasyonun sürdürülebilirliği ve planlaması üzerinde yoğunlaştığı görülmektedir.

Ekonomik ve coğrafi kapsamı ile beraber önemli bir konumda yer alan turizm sektörü, aynı zamanda pek çok küresel sorunun çözümünde de üstlendiği rol sebebiyle sürdürülebilir turizm konusuna dikkat çekmektedir. Çalışma kapsamında; sürdürülebilir turizm konusunda lisansüstü tezlerin daha çok yüksek lisans düzeyinde yapıldığı görülmektedir. Akademik düzeyde yapılacak olan çalışmaların ve araştırmaların özellikle sektör yöneticilerine ve turizm planlamacılarına katkı sağladığı dikkate alındığında sürdürülebilir turizm konusunun üzerinde daha çok durulması gerektiği ortaya çıkmaktadır. Bu bağlamda, turizm sektörü içerisinde pek çok açıdan ağırlıklı bir yapı ortaya koyan sürdürülebilir turizm konulu çalışmaların nicelik ve özellikle de nitelik olarak arttırılmasında fayda görülmektedir.

Gelecekte yapılacak çalışmalarda sürdürülebilir turizm konulu tezler, kullanılan yöntemler açısından incelenebilir. Ayrıca yapılacak çalışmalarda tezlerin amaçları ve sonuçları değerlendirilerek sürdürülebilir turizm konusuna yönelik kapsam dikkate alınabilir ve hangi yönlerden ele alındığı belirlenerek konu derinlemesine irdelenebilir. $\mathrm{Bu}$ çalışmanın da her çalışmada olduğu gibi bazı sınırlılıkları olmuştur. Araştırmada incelenen tezlerin yalnızca YÖK veri tabanına kaydedilmiş tezler olması ve bu nedenle henüz veri tabanına girişi yapılmayan tezlerin kapsam dışı kalmış olma olasıllığ bu çalışmanın bir sınırılığıdır. Çalışma kapsamında sadece son 11 yıldaki lisansüstü tezler değerlendirmeye alınmıştır. İlgili yıllar arasında yayınlanmış fakat bu çalışma kapsamında ulaşılamamış tezlerin de olması muhtemeldir.

\section{Kaynakça}

Al, U. ve Coştur, R. (2007), 'Türk Psikoloji Dergisi'nin Bibliyometrik Profili' Türk Kütüphaneciliği, 21 (2), ss. 142-163.

Arıca, R. (2014), Seyahat İşletmeciliği Literatürünün Gelişim Süreci: Türkiye'de Hazırlanan Lisansüstü Tez Çalışmalarının Bibliyometrik Olarak İncelenmesi, VII. Lisansüstü Turizm Öğrencileri Araştırma Kongresi, 04-05 Nisan 2014, Kuşadası, Aydın, ss. 446-462.

Avcıkurt, C.(2015), Turizm Sosyolojisi (Genel ve Yapısal Yaklaşım), Yenilenmiş ve Genişletilmiş 4. Baskı, Ankara: Detay Yayıncılık.

Aydın, B. (2014), Yükseköğretim Kurulu Tez Merkezinde (YÖKTEZ) Yiyecek İçecek İşletmeciliği Alanında Kayıtlı Bulunan Tezlerin Bibliyometrik Analizi, VII. Lisansüstü Turizm Öğrencileri Araştırma Kongresi, 04-05 Nisan 2014, Kuşadası, Aydın, ss. 55-70.

Cevizkaya, G., Avcıkurt, C. ve İlsay, S. (2014), Turizm Alan Yazınında Engelliler İle Illgili Çalışmaların Bibliyometrik Profili (2000-2013), 15. Ulusal Turizm Kongresi, Gazi Üniversitesi, Ankara, ss. 145- 151.

Çalık, İ. (2014), Sürdürülebilir Turizm Göstergeleri Kapsamında Doğu Karadeniz Bölgesi'nin Analizi, Yayınlanmamış Doktora Tezi, Sakarya Üniversitesi, Sosyal Bilimler Enstitüsü, Sakarya.

Çiçek, D. ve Kozak, N. (2012), Anatolia: Turizm Araştırmaları Dergisi'nde Yayımlanan Hakem Denetimli Makalelerin Bibliyometrik Profili, VI. Lisansüstü Turizm Öğrencileri Araştırma Kongresi, 12-15 Nisan 2012, Kemer, Antalya, ss. 196-211. 
Güçlü Nergiz, H. (2014), Türkiye'de Lisansüstü Turizm Tezlerinin Bibliyometrik Profili (1990-2013), VII. Lisansüstü Turizm Öğrencileri Araştırma Kongresi, 04-05 Nisan 2014, Kuşadası, Aydın, ss. 212-221.

Keleş, M. Ç., Pelit, E., Keleş, Y. ve Pelit, N. (2015), Ekoturizmin Kırsal Kalkınmaya Etkisine Yönelik Yerel Halkın Algılamaları: İnece Ekoturizm Köyü Örneği, Doğu Karadeniz Bölgesi Sürdürülebilir Turizm Kongresi, 14-16 Mayıs 2015, Gümüşhane Üniversitesi, Gümüşhane, ss. 466-475.

Keskin, E. ve Örgün, E. (2015), 'Kelime İlişkilendirme Testi Aracılığıyla Sürdürülebilir Turizm Olgusunun Kavramsal Analizi: Ürgüp Örneği', Journal of Tourism and Gastronomy Studies, 3 (1) ss. 30-40.

Kodaş, D. (2014), International Journal of Wine Business Research (IJWBR) Dergisinin Bibliyometrik Özellikleri Açısından İncelenmesi, VII. Lisansüstü Turizm Öğrencileri Araştırma Kongresi, 04-05 Nisan 2014, Kuşadası, Aydın, ss. 98-112.

Kozak, N. (2000), 'Türkiye'de Akademik Turizm Literatürünün Gelişim Süreci Üzerine Bir İnceleme', DAÜ: Turizm Araştırmaları Dergisi, 1 (1), ss. 15-55.

Kozak, N. (2001), 'Türkiye'de Turizm Pazarlaması Literatürünün Gelişim Süreci: 19721998 Yılları Arasında Hazırlamış Lisansüstü Tez Çalışmaları Üzerine BiyoBibliyografik Bir Inceleme', Anatolia: Turizm Araştırmaları Dergisi, 12, ss. 26-33.

Kuşat, N. (2011), Turizm Sektöründe Küreselleşmenin Etkisi ve Rekabet Üstünlüğünün Sürdürülebilirliği. 12. Ulusal Turizm Kongresi, 30 Kasım-4 Aralık 2011, Düzce Üniversitesi, Akçakoca, ss. 32-41.

Özel, Ç. H. ve Kozak, N. (2012), 'Turizm Pazarlaması Alanının Bibliyometrik Profili (2000-2010) ve Bir Atıf Analizi Çalışması', Türk Kütüphaneciliği, 26 (4), ss. 715733.

Swarbrooke, J.(1999), Sustainable Tourism Management, 2nd Edition, London: CABI Publishing.

Şahin, S. ve Acun, A. (2015), Turist Rehberliği Alanının Bibliyometrik Profili (Makaleler ve Lisansüstü Tezler), 16. Ulusal Turizm Kongresi, Çanakkale Onsekiz Mart Üniversitesi, Çanakkale, ss. 1456-1475.

Şakar Denktaş, G. ve Cerit, A. G. (2013), 'Uluslararası Alan İndekslerinde Türkiye Pazarlama Yazını: Bibliyometrik Analizler ve Nitel Bir Araştırma', Atatürk Üniversitesi İktisadi ve Idari Bilimler Dergisi, 27 (4), ss. 37-62.

Temizkan, S. P., Çiçek, D. ve Özdemir, C. (2015), 'Sağlık Turizmi Konusunda Yayınlanan Makalelerin Bibliyometrik Profili', International Journal of Human Sciences, 12 (2), ss. 394-415.

Turan, A. (2014), Turizm Konulu Yüksek Lisans Tezlerinin Bibliyometrik Özellikleri (1984-2013), VII. Lisansüstü Turizm Öğrencileri Araştırma Kongresi, 04-05 Nisan 2014, Kuşadası, Aydın, ss. 3-15.

Ulu, S. ve Akdağ, M. (2015), 'Dergilerde Yayınlanan Hakem Denetimli Makalelerin Bibliyometrik Profili: Selçuk İletişim Örneği', Selçuk Iletişim, 9 (1), ss. 5-21.

Yozgat, U. ve Kartaltepe, N. (2009), 'Ulusal Yönetim ve Organizasyon Kongre Kitaplarında Yer Alan Bildirilerin Bibliyometrik Profili: Örgüt Teorisi ve Örgütsel Davranış Bildirileri Üzerine Bir Araştırma', Eskişehir Osmangazi Üniversitesi IíBF Dergisi, 4 (1), ss. 149-165.

YÖK (2015), https://tez.yok.gov.tr/UlusalTezMerkezi/lstatistikiBilgiler?islem=3 (25.12.2015).

Zan, B. U. (2012), Türkiye'de Bilim Dallarında Karşılaştırmalı Bibliyometrik Analiz Çalışması, Yayınlanmamış Yüksek Lisans Tezi, Ankara Üniversitesi, Sosyal Bilimler Enstitüsü, Ankara.

Ziegler, B. (2009). Methods for Bibliometric Analysis of Research: Renewable Energy Case Study, Composite Information Systems Laboratory (CISL) Sloan School of Management Working Paper, Cambridge, http://web.mit.edu/smadnick/www/wp/2009-10.pdf (30.12.2015). 